\title{
Bullying in the Bahamian Workplace
}

\author{
William J. Fielding (Dhttps://orcid.org/0000-0001-5433-9673 \\ Institutional Strengthening \& Accreditation
}

University of The Bahamas

https://doi.org/10.15362/ijbs.v26i0.355

\section{Abstract}

This paper reports the first known study on workplace bullying in The Bahamas. Over 2,000 people participated in an Internet-based study in the spring of 2020. The data suggest that $22 \%$ of the workforce may suffer from severe workplace bullying. This is a relatively high figure and is a potential cause for concern. While no difference in the rate of bullying between male and female workers was identified, the underlying associations which appear to put males and females at risk of workplace bullying vary. For both males and females, exposure to negative behaviours at home and school were associated with elevated rates of workplace bullying.

My manager had a nickname for me because I'm disabled: "damaged goods." My manager and my boss were not the nicest people, and they were constantly looking over my co-workers and my shoulders. The pair were smiley to our faces but to other co-workers they would say rude and inappropriate remarks not realizing that my co-workers and I tell each other everything! (Participant A, 2020)

\section{Introduction}

While workplace bullying has attracted the attention of researchers for some time, differences in defining and measuring it persist (for example, Lewis et al., 2008; Anjum et al., 2019). Anjum et al. (2019) suggest a concise definition: "workplace bullying is essentially about purposeful breaches of an individual's space of dignity, rights, and integrity" (p. 1). For behaviours to be considered bullying, they must occur regularly, occur over a prolonged period of time and arise from a power inequality between the victim and the bully (Anjum et al., 2019). In their review of the components of bullying, Cowie et al. (2002) considered not only types of bullying activities but also the frequency of bullying, imbalance of power, perspective of the "victim" and "victimizer", and workplace culture. While there appears to be no single definition of workplace bullying, it is recognized that the actions must be repetitive and the victims must have difficulty in defending themselves from the victimiser (Illing et al., 2016). Workplace bullying has been viewed as demonstrating parallels with school bullying, due to or arising from an imbalance of power (Cowie et al., 2002).

In The Bahamas, bullying is commonly associated with children in a school setting where one student exerts some sort of power over another ("Bittersweet end to summer", 2011). In 2012, it was found that $26 \%$ of boys and $17 \%$ of girls have been physically bullied ("The Crime of Bullying", 2014). Bullying at school is not dissimilar to the workplace when either peers or those in authority use their position, or some other perceived advantage, to exert some sort of power over another. This has parallels with the use of punishment in the home where the discipline/punishment is exerted by siblings or parents to correct/control behaviours which are deemed undesirable. Further, in the 
case of interpersonal violence, the victim can be subjected to physical or emotional harm as victimizers attempt to force victims to conform to their wishes. Abusive behaviours, including harsh discipline and other behaviours of concern, have been documented in The Bahamas by Fielding et al. (2016) and the fact that prisoners demonstrate higher rates of victimization compared to the general population heightens the concern. Therefore, the workplace can become another manifestation of the power struggle between people, which can occur in a number of different settings throughout their lives.

Negative workplace behaviours have been the focus of considerable research worldwide and, in the United States, Clark et al. (2013) indicate that workplace incivility is getting worse. Amongst the mix of factors which contribute to workplace bullying are gender and management (Sansone \& Sansone, 2015). In Italy, for example, females have been found to be at greater risk of bullying than men (Campanini et al., 2006). Further differences between the sexes with regard to workplace bullying have been attributed to factors beyond the workplace such as child rearing (Tonini et. al., 2011). Research has resulted in identifying negative consequences to both the employee (Tuckey \& Neall, 2014) and the economy, which result from bullying at work (Vega \& Comer, 2005).

Workplace bullying has been found to have negative consequences beyond the victim (Vartia, 2001) and the effects of workplace bullying can be long-term (Nielsen et al., 2012) and lead to depression (Theorell et al., 2015). An examination of the effects of workplace bullying in Barbados highlighted the association of workplace bullying and various negative effects, such as exhaustion and depression, but not sick leave mandated by a doctor (Devonish, 2013). A study from
Jamaica, Barbados and Trinidad and Tobago noted the linkage between workplace bullying and intentions to leave the workplace, a finding which is consistent with the wider literature (Singh, 2018). In Trinidad and Tobago, 54\% of nurses, the majority of whom were female, reported being intimidated at work, putting them at the higher end of reported workplace bullying worldwide (Onuoha et. al, 2014). Workplace bullying reduces engagement in work as it reduces the level of job satisfaction (Trépanier et al., 2013).

Complaints by various groups that the Bahamian workforce lacks soft skills and offers poor customer service (Fazio \& Pinder, 2014) may be influenced by the bullying which takes place in the workplace; that is, employee dissatisfaction with their work is reflected in their treatment of customers. Customer service is a key feature of tourism so, in a tourism-based economy, bullying may have important economic consequences.

While no study on workplace bullying in The Bahamas appears to have been published, generic newspaper articles (for example, Ranger, 2018) and reports highlight that some members of the workplace feel they have been bullied or victimized. One aspect which is admitted is that of "political bullying” (Strachan, 2012; Hanna, 2020).

It should be noted that workplace bullying occurs across a range of regions as well as gender (de Smet et al., 2005) and occupational areas (Illing et al., 2016). Even in a university setting in the Czech Republic, $13.6 \%$ of employees have been victims of bullying (Zabrodska \& Kveton, 2013). Of interest is that in the absence of public studies on workplace bullying in The Bahamas, it is recognised that workplace bullying can be detrimental to the functioning of businesses (Ferguson, 2012). 
While it is appreciated that violence in various forms occurs in Bahamian society (Fielding et al., 2016), it has also been noted that various forms of violence and attitudes towards the acceptance of violent behaviours can be higher in The Bahamas than elsewhere in the region (Sutton \& Álvarez, 2016). If rape and murder are considered as arising from extreme forms of bullying, the relatively high figures attributed to The Bahamas indicate that bullying in its most general form can be considered a cause for concern. Within Bahamian society there is much concern about gender-based violence as is reflected in the Strategic Plan to End Gender-based Violence in The Bahamas (Bahamas National Task Force for Genderbased Violence, 2015).

Due to the fact that different forms of violence and their associated fears are associated more with one sex than the other (for example, rape in the case of females, Bethel and Fielding [2020] and Fielding [2019] and murder in the case of males [Hanna, 2017]), the results from this study are indexed by sex. Further, as has been demonstrated previously, women in The Bahamas typically have more years of education than men, although they get paid less for their employment (Fielding, 2014), a situation which persists (Bahamas Department of Statistics, 2019). Hence there are structural imbalances which disfavour women and which demonstrate the structural inequalities which women face in The Bahamas (Fielding \& Ballance, 2019). Therefore, it is appropriate to consider workplace bullying by sex to ascertain whether there are gender-based differences in this interpersonal behaviour.

Arising from the concerns such as those outlined above, a study was undertaken in February/March 2020 to obtain some preliminary data as to how common workplace bullying might be in The Bahamas and what may be some of the influences with which it is associated. In particular, the study set out to: (1) demonstrate the presence of bullying in the Bahamian workplace, (2) examine how workplace bullying might vary between men and women, (3) determine whether workplace bullying might vary between workplaces, (4) uncover linkages, if any, between workplace bullying and a person's intention to leave that workplace, and (5) uncover linkages, if any, between negative experiences in the life of the worker outside of the workplace and their experience of bullying at work. Information on these issues would assist in situating The Bahamas within the wider context of workplace bullying. Also, information might highlight the need for training and awareness of any negative consequences of bullying and ultimately any constraint it might impose on the prosperity of the country.

\section{Method}

In assessing negative workplace behaviours in the National Health Service in the United Kingdom, Illing et al. (2016) gave a review of helpful measures. Consistent with other researchers, we use the Negative Acts Questionnaire-Revised (NAQ-R) in Einarsen et al. (2009). This scale, which has been used in numerous settings, allows us to locate the findings from this study in the wider literature on workplace bullying.

The NAQ-R considers workplace bullying in three dimesons. The 22 items cover: (a) work bullying, (b) personal bullying, and (c) physical intimidation. For this study, an Internet-based survey was devised which included the NAQ-R. In appreciation that a person's perception is their reality, a simple perception question regarding being bullied at work was also asked of each participant. In addition, information on the participant's workplace-such as the nature of the 
employer, the area of the economy in which the respondent worked, simple demographics, information on school bullying, exposure to childhood discipline, violence in the home and intimate partner violence (IPV) were collected. IPV focused on physical violence between intimate partners as this is a key feature of IPV and sexual abuse in The Bahamas (Bethel \& Fielding, 2020). Questions on turn-over intentions were taken from Van Dyck (2013). Qualitative data were also collected from respondents who wished to share their experiences of workplace bullying. Some of these responses are quoted verbatim.

The study's target population was adults aged 18 or over who were in paid employment and ordinarily resident in The Bahamas. Respondents were recruited via a snowball sample using the contacts of university students as the starting point. Recipients of the request to participate were asked to forward the survey link to persons in their contact groups. It was expected that this method would result in a sample of 2,100 respondents as each student was asked to recruit 100 respondents. It was anticipated that this approach would result in a large number of respondents from different sectors of the economy, from workers from across the country, and so allow for the linkages between any negative experiences inside and outside the workplace to be assessed.

This study was approved by the Institutional Review Board (IRB) of University of The Bahamas and the requisite permission to use the Revised (NAQ-R) Scale was obtained.

\section{Results}

A total of 2,579 people entered the survey, 12 declined to participate. Of the total, 2,123 were currently employed and receiving money for their labour and were ordinarily resident in The Bahamas. Further, some people who entered the survey answered very few answers or were under the age of 18; one person did not give their sex and nine identified their sex as "other". As a result, 2,060 respondents were retained in the dataset. Not all of these respondents answered every question and so this represents the maximum number of respondents to any particular question.

\section{Overview of participants}

The majority of participants were female (70.6\%). As nine respondents gave their sex as "other", they were omitted when the data are presented by sex. The modal age group was $28.9 \%$ (of 2,058) and modal time in the workforce was 20 years or more $(33.1 \%)$. Most respondents were currently employees (96.4\% of 1,713 responses) and $3.6 \%$ were self-employed. The distribution of the highest level of education attained is shown in Table 1, with females being more likely than males to have post-high school education $\left(\chi^{2}=59.5, d f=6, N=2055, p<\right.$ $.001)$.

Table 1

Respondents' highest level of completed education, \%s within sex

\begin{tabular}{|c|c|c|}
\hline $\begin{array}{l}\text { Highest level of education } \\
\text { completed }\end{array}$ & Male & Female \\
\hline Less than high school & 0.7 & 0.4 \\
\hline High school & 35.8 & 26.9 \\
\hline $\begin{array}{l}\text { Post high school } \\
\text { vocational training }\end{array}$ & 15.8 & 13.7 \\
\hline Associate's degree & 15.1 & 18.2 \\
\hline Bachelor's degree & 15.4 & 25.6 \\
\hline $\begin{array}{l}\text { Master's degree or higher } \\
\text { Professionally }\end{array}$ & 8.3 & 8.9 \\
\hline $\begin{array}{l}\text { recognized } \\
\text { qualification (e.g.: CPA } \\
\text { etc.) }\end{array}$ & 8.6 & 6.3 \\
\hline$N$ & 603 & 1,452 \\
\hline
\end{tabular}


Experiences of negative behaviours outside the workplace

Participants' experiences of violence outside of the workplace were common. Most participants had been hit by a household member, with boys being most likely to suffer from violence as a result of an object $\left(\chi^{2}=31.3, d f=3, N=1,594, p<.001\right)$, (see Table 2). A minority of participants had not been hit at home as a means of punishment.

\section{Table 2}

Respondents' experience of violent punishment at home, \% within sex

\begin{tabular}{lcc}
\hline $\begin{array}{l}\text { When growing up, hit as } \\
\text { punishment by a } \\
\text { household member }\end{array}$ & Male & Female \\
\hline $\begin{array}{l}\text { With the hand } \\
\text { With an object (switch, }\end{array}$ & 23.5 & 31.3 \\
$\begin{array}{l}\text { strap, etc.) } \\
\text { I would consider this }\end{array}$ & 65.6 & 50.7 \\
$\begin{array}{l}\text { punishment abuse } \\
\text { Not hit }\end{array}$ & 4.6 & 7.4 \\
\hline$N$ & 6.3 & 10.6 \\
\hline
\end{tabular}

Bullying at school occurred almost equally between the sexes $\left(\chi^{2}=1.85, d f=2, N=\right.$ $1,593, p=.40)$ and about one third of both males and females claimed to be victims of school bullying (see Table 3). These figures are higher than those reported in 2012 ("The Crime of Bullying," 2014); however, that study reported on physical bullying.

\section{Table 3}

Respondents' experience of bullying at school, \% within sex

\begin{tabular}{lcc}
\hline Bullied at school & Male & Female \\
\hline Yes & 36.8 & 33.5 \\
No & 55.9 & 58.2 \\
Not sure & 7.3 & 8.3 \\
\hline$N$ & 478 & 1,115 \\
\hline
\end{tabular}

Similarly, both male and female participants emerged from homes where their mothers were equally likely to have be abused $\left(\chi^{2}=\right.$ 2.76, $d f=2, N=1,612, p=.25$; see Table 4), and about one third of both males and females claimed to be victims of bullying.

Table 4

Respondents' recalling their mother being hit by her imitate partner, $\%$ within sex

\begin{tabular}{lcc}
\hline Mother hit & Male & Female \\
\hline Yes & 13.0 & 16.3 \\
No & 84.2 & 81.2 \\
Do not remember & 2.7 & 2.6 \\
\hline$N$ & 476 & 1,136 \\
\hline
\end{tabular}

Of those participants who had engaged in sexual intercourse, women were more likely than men to have been hit by their intimate partner $\left(27.3 \%\right.$ cf $15.5 \% ; \chi^{2}=16.5, d f=1, N$ $=1,022, p=<.001)$.

\section{Respondents' perceptions of their workplace bullying}

In Tables 5 to 13, we report workplace bullying as perceived by the respondent, not through the NAQ-R scale. Women were more likely than men to feel they had been ever bullied in the workplace $\left(\chi^{2}=16.2, d f=\right.$ $3, N=2,058, p=.001$; see Table 5), demonstrating that women are more likely than men to emerge from a violent home to work in what they perceive to be a hostile work environment.

\section{Table 5}

Respondents' perception of being ever bullied in the workplace, $\%$ within sex

\begin{tabular}{lcc}
\hline Ever bullied & Male & Female \\
\hline Yes & 30.2 & 38.0 \\
No & 61.8 & 52.3 \\
Not sure & 4.3 & 5.9 \\
This is my first job & 3.6 & 3.9 \\
\hline$N$ & 605 & 1,453 \\
\hline
\end{tabular}


As noted in Table 1, females in the study reported more education than males. As education is associated with employment opportunities, it is useful to examine the link between education and bullying. Table 6 indicates that women with higher levels of educational attainment are more likely to report being bullied than men with the corresponding level of education. Therefore, education does not appear to be a protective factor for women from bullying. For both men and women, bullying rates differed with the level of education attained.

Table 6

Percentage of respondents, by sex, being bullied with highest level of education completed.

\begin{tabular}{llll}
\hline Highest level of education completed & Male & Female & $\chi^{2} p=$ \\
\hline Less than high school* & 0.0 & 66.7 & - \\
High school & 22.0 & 20.5 & .89 \\
Post high school vocational training & 24.7 & 23.5 & .67 \\
Associate's degree & 28.7 & 25.6 & .48 \\
Bachelor's degree & 10.5 & 25.9 & .006 \\
Master's degree or higher & 23.3 & 38.6 & .040 \\
Professionally recognized qualification (e.g.: CPA, etc.) & 9.1 & 32.0 & .003 \\
\hline$N$ & 509 & 1,452 & \\
\hline
\end{tabular}

Note: *Percentages in this group are based on four observations for men and six for females.

Men were more likely than women to work in multiple workplaces $\left(\chi^{2}=14.2, d f=3, N=\right.$ 2,042, $p=.003)$, Table 7. It was in anticipation of such a result, based upon other studies in The Bahamas (for example, Fielding et al., 2019) which indicate that people have more than one job, that when participants were asked about their negative workplace experiences in their current work place, they were asked to select just one current workplace and report on that one job only.

Table 7

Number of places of work, \% within sex

\begin{tabular}{lll}
\hline Number of workplaces & Male & Female \\
\hline 1 & 67.6 & 75.4 \\
2 & 20.2 & 15.0 \\
3 & 4.7 & 3.1 \\
More than 3 & 7.5 & 6.6 \\
\hline$N$ & 599 & 1,443 \\
\hline
\end{tabular}

When asked about their perception of bullying in their current job, females were slightly more likely than men to consider themselves bullied; however, the difference just failed to reach a formal level of statistical significance $\left(\chi^{2}=5.74, d f=2, N=1,698, p=\right.$ $.057)$, about one in four respondents felt bullied (Table 8).

Table 8

Respondents' perceptions of being bullied in their present workplace, \% within sex

\begin{tabular}{lll}
\hline Currently bullied & Male & Female \\
\hline Yes & 20.6 & 25.9 \\
No & 69.4 & 64.1 \\
Not sure & 10.0 & 10.0 \\
\hline$N$ & 510 & 1,188 \\
\hline
\end{tabular}

The consequences of this bullying can be appreciated in that both and males and females were more likely to be thinking of leaving their workplace than if they had not been bullied, and not even just change jobs 
within the same workplace (Table 9). Bullying had an even greater impact on respondent happiness in the workplace, with a lowered likelihood of respondents being happy when they were bullied. Females who felt bullied were even less likely than males to feel happy in their jobs. This attitude reflected in them being more likely to think of changing their job. Consequently, workplace bullying has the potential to produce greater instability in the female rather than male workforce. This may mean that in those areas of the workplace dominated by females, such as nursing and education, the effects of workplace bullying might be most marked. In addition to wanting to leave the workplace, as illustrated by one participant, being bullied can result in reduced creativity:
My superior was very controlling, gave impossible deadlines, always said no, shut you down if you tried make suggestions, really stifled creativity and independence. The worst was they never defended the staff, preferring to ally themselves with the senior management. As a result, I simply stopped offering suggestions because they would not be accepted. It got the point where I wanted to quit. I took my personal effects home and prepared a resignation letter. In retrospect, I suppose the superior was afraid of being shown up as incompetent, so that is why they exhibited that imperious behaviour. But not taking the staff's side made the work environment intolerable. (Participant B, 2020)

Table 9

Association between bullying and turnover intentions, \% within sex

\begin{tabular}{lcccc}
\hline \multirow{2}{*}{ Those agreeing with: } & \multicolumn{2}{c}{ Male } & \multicolumn{2}{c}{ Female } \\
& Bullied & Not Bullied & Bullied & Not Bullied \\
\hline Wanting to move jobs, but remaining in the & 48.7 & 28.9 & 48.2 & 22.3 \\
same workplace & 60.1 & 35.9 & 68.8 & 33.2 \\
Thinking of about leaving this workplace & 48.1 & 72.0 & 36.7 & 73.5 \\
Overall feeling happy with this job & 100 & 350 & 300 & 740 \\
\hline$N \approx$ & Note: All differences between the bullied verses not bullied figures have a $\chi^{2}$ test significant at $p<.001$
\end{tabular}

Employees on a fixed contract were at greatest risk of feeling bullied, but this difference was not statistically significant for males. However, women on fixed term contacts felt most likely of all female employment groups to be victims of bullying (see Table 10).
Table 10

Percentage of respondents by sex, within terms of employment, who reported being bullied

\begin{tabular}{lll}
\hline Terms of employment & Male & Female \\
\hline Permanent contract & 18.6 & 27.0 \\
Fixed term contract & 24.7 & 30.5 \\
No contract with & & \\
employer & 17.4 & 18.9 \\
Self employed & 21.1 & 16.0 \\
Other & 14.3 & 31.4 \\
$\chi^{2} p=.1$ for males, and $p=.029$ for females.
\end{tabular}


For both males and females, employment by the government puts them at greater risk of being bullied than working elsewhere (see Table 11).

\section{Table 11}

Percentage of respondents by sex being bullied by nature of employer

\begin{tabular}{lll}
\hline Employer & Male & Female \\
\hline Self employed & 16.8 & 20.0 \\
Government & 30.3 & 33.4 \\
Private sector & 18.4 & 25.4 \\
\hline$N$ & 458 & 1062 \\
\hline$\chi^{2} p=.011$ for males, and $p=.011$ for females.
\end{tabular}

Even at the senior levels, women at management levels reported being just as likely to be bulled than women at nonmanagement levels $\left(\chi^{2}=15.14, d f=12, N=\right.$ $1,171, p=.234)$. This was in contrast to the pattern of bullying in males $\left(\chi^{2}=29.3, d f=\right.$ $12, N=510, p=.004)$, where managerial positions appear to protect them from being bullied (see Table 12). As might be expected, managers tended to be less bullied than those in less senior positions.

Table 12

Percentage of respondents reporting being bullied by position and sex in the workplace

\begin{tabular}{lrc}
\hline Position in the workplace & Male & Female \\
\hline Senior manager & 12.7 & 20.7 \\
Manager & 16.4 & 26.5 \\
Supervisor & 24.7 & 29.7 \\
Technical support & 12.0 & 19.7 \\
Secretarial/clerk & 31.6 & 28.0 \\
Manual staff & 30.6 & 28.1 \\
Other & 11.5 & 22.7 \\
\hline
\end{tabular}

Although not the focus of this study, one participant provided an insight as to how managers can bully through the imbalance of power:
My direct line of report includes bullying from two persons: One is incompetent but is unaware of said incompetence which results in her tyrannical style of management. This person's 'leadership' style includes shouting, humiliating employees, threats of termination, etc. The other is an absolute bully and is allowed to continue this behaviour because of some perceived special skillset that she possess. This person exhibits bullying by shouting, lying, withholding pertinent information. It is widely known and accepted that if she is mad at you there will be adverse consequences as she will use her influence to your detriment.

Associations between negative experiences in the life of the worker and workplace bullying

The effect of earlier violence in the lives of participants was associated with different impacts on their risk of being bullied in the workplace (Table 13). While men were more resilient to being hit at home or seeing their mother being hit by her intimate partner compared to females, bullying at school was associated with increased workplace bullying for both males and females. While the percentages of men who were bullied in the work were higher than when they have been exposed to childhood violence compared to not being exposed, the increase was less marked for men than for women. So typically, violent experiences outside of the workplace are more likely to be associated with increasing rates of bullying. Therefore, the possible effects of violence outside of work are important in the work life of both men and women. 
Table 13

Respondents' experiences of childhood violence and being bullied in the workplace, \% by sex within level of childhood violence

\begin{tabular}{|c|c|c|c|c|c|c|}
\hline \multirow{2}{*}{$\begin{array}{l}\text { Childhood } \\
\text { experiences } \\
\text { of violence }\end{array}$} & \multicolumn{2}{|c|}{ Male } & \multicolumn{3}{|c|}{ Female } & \multirow[b]{2}{*}{$\chi^{2} p$} \\
\hline & $\begin{array}{l}\text { Bullied } \\
\text { at work }\end{array}$ & $\begin{array}{l}\text { Not bullied } \\
\text { at work }\end{array}$ & $\chi^{2} p$ & $\begin{array}{l}\text { Bullied at } \\
\text { work }\end{array}$ & $\begin{array}{l}\text { Not bullied } \\
\text { at work }\end{array}$ & \\
\hline Hitting at home was abusive & 9.4 & 3.1 & .028 & 12.4 & 5.0 & $<.001$ \\
\hline Bullied at school & 54.2 & 30.8 & $<.001$ & 51.9 & 23.6 & $<.001$ \\
\hline $\begin{array}{l}\text { Hit by respondent's intimate } \\
\text { partner }\end{array}$ & 19.2 & 13.1 & .145 & 31.8 & 23.6 & .008 \\
\hline $\begin{array}{l}\text { Mother hit by intimate } \\
\text { partner }\end{array}$ & 13.7 & 12.7 & 0.82 & 21.1 & 14.1 & $<.001$ \\
\hline
\end{tabular}

Note: *Hit as a means of discipline

Experience of bullying measured by NAQ-R

The NAQ-R is a validated measure for assessing workplace bullying. Thus, while the respondent's perceptions of bulling are important, this scale allows for those who may have been bullied, yet deny it, to be correctly identified. Notwithstanding the limitations of this study (discussed below), the use of this scale also allows for the results from this study to be compared with other studies which have used this scale.

Cronbach's alpha for the NAQ-R scale was good at .94. The most widespread experience of bullying related to having opinions ignored, withholding information and spreading gossip, which were experienced by about $60 \%$ of respondents (Table 14). Excessive monitoring of work and being asked to do work below the level of the respondent's competence were reported to occur on a daily basis by about $10 \%$ of respondents. Overall, there were few differences in the experiences of males and females. Being humiliated or ridiculed in connection with work was a little more likely to be experienced by females $(46.3 \%)$ than males $(41.5 \%)$. Although this difference was not statistically significant $\left(\chi^{2}=5.09, d f=4\right.$ $N=1,719, p=.278)$, the Binomial Effect Size Display is $5.4 \%$ with an Effect Size of .119. As Cohen's $d=.12$ is relatively large, this difference should not be overlooked (Lenhard \& Lenhard, 2016). Overall, 7.8\% of male and $5.7 \%$ of female respondents have never experienced any of the actions listed in Table 14 which indicates that most members of the workforce suffered some form of workplace bullying. Table 14 also indicates that the most common elements of workplace bullying are associated with work-related bullying (WR) and that physical intimidation (PI), while relatively rare, occurred between one in five and one in ten participants. The quotation above from a participant also illustrates what can be appreciated from Table 14.

The bullying scores from the NAQ-R can be used to determine the level of bullying experienced by respondents (Notelaers \& Einarsen, 2013). It is evident that there is little difference in the exposure of males and females to bullying ( $\chi^{2}=.82, d f=2, N=$ $1,619, p=.67)$, which is at variance to the perception of respondents and their selfreported perceptions of bullying (see Table 15). This suggests that respondents may be including behaviours which are not included in this scale, or there are deeper dissatisfactions with the workplace which are not actually bullying actions. 
Table 14

Respondents' experiences of bullying activities, in the NAQ-R \% by sex

\begin{tabular}{|c|c|c|c|c|c|}
\hline \multirow[b]{2}{*}{ Factor } & \multirow[b]{2}{*}{ Bullying action } & \multicolumn{2}{|c|}{ Experienced daily } & \multicolumn{2}{|c|}{ Ever experienced } \\
\hline & & Male & Female & Male & Femal \\
\hline WR & Having your opinions ignored & $6.9 \%$ & $6.3 \%$ & $60.3 \%$ & $60.4 \%$ \\
\hline WR & $\begin{array}{l}\text { Someone withholding information which affects } \\
\text { your performance }\end{array}$ & $8.0 \%$ & $6.6 \%$ & $59.9 \%$ & $60.9 \%$ \\
\hline PR & Spreading of gossip and rumours about you & $7.4 \%$ & $6.2 \%$ & $59.2 \%$ & $61.3 \%$ \\
\hline WR & Excessive monitoring of your work & $10.2 \%$ & $10.4 \%$ & $56.2 \%$ & $56.3 \%$ \\
\hline PR & Being ignored or excluded & $3.7 \%$ & $6.3 \%$ & $55.6 \%$ & $60.2 \%$ \\
\hline WR & $\begin{array}{l}\text { Being ordered to do work below your level of } \\
\text { competence }\end{array}$ & $10.3 \%$ & $8.5 \%$ & $53.9 \%$ & $52.3 \%$ \\
\hline WR & Being exposed to an unmanageable workload & $7.7 \%$ & $8.6 \%$ & $50.4 \%$ & $54.9 \%$ \\
\hline WR & Being given tasks with unreasonable deadlines & $6.3 \%$ & $5.6 \%$ & $50.3 \%$ & $53.1 \%$ \\
\hline PR & $\begin{array}{l}\text { Having key areas of responsibility removed or } \\
\text { replaced with more trivial or unpleasant tasks }\end{array}$ & $5.4 \%$ & $4.8 \%$ & $49.0 \%$ & $43.8 \%$ \\
\hline PR & $\begin{array}{l}\text { Having insulting or offensive remarks made about } \\
\text { your person, your attitudes, or your private life }\end{array}$ & $5.2 \%$ & $4.6 \%$ & $45.0 \%$ & $47.6 \%$ \\
\hline PR & Repeated reminders of your errors or mistakes & $4.7 \%$ & $2.9 \%$ & $44.7 \%$ & $45.5 \%$ \\
\hline PR & $\begin{array}{l}\text { Being humiliated or ridiculed in connection with } \\
\text { your work }\end{array}$ & $3.1 \%$ & $3.3 \%$ & $41.5 \%$ & $46.3 \%$ \\
\hline PR & Having allegations made against you & $5.3 \%$ & $3.0 \%$ & $41.2 \%$ & $40.9 \%$ \\
\hline PR & $\begin{array}{l}\text { Pressure not to claim something to which by right } \\
\text { you are entitled (e.g., sick leave, holiday) }\end{array}$ & $5.1 \%$ & $5.5 \%$ & $38.4 \%$ & $39.9 \%$ \\
\hline PR & $\begin{array}{l}\text { Being shouted at or being the target of } \\
\text { spontaneous anger }\end{array}$ & $2.7 \%$ & $3.4 \%$ & $35.8 \%$ & $37.5 \%$ \\
\hline PR & $\begin{array}{l}\text { Being ignored or facing a hostile reaction when you } \\
\text { approach }\end{array}$ & $2.3 \%$ & $3.2 \%$ & $34.5 \%$ & $38.3 \%$ \\
\hline PR & Persistent criticism of your errors or mistakes & $3.3 \%$ & $3.7 \%$ & $34.1 \%$ & $35.9 \%$ \\
\hline PR & $\begin{array}{l}\text { Practical jokes carried out by people you don't get } \\
\text { along with }\end{array}$ & $3.3 \%$ & $4.1 \%$ & $30.6 \%$ & $30.7 \%$ \\
\hline PR & $\begin{array}{l}\text { Hints or signals from others that you should quit } \\
\text { your job }\end{array}$ & $4.3 \%$ & $3.4 \%$ & $28.7 \%$ & $29.9 \%$ \\
\hline $\mathrm{PI}$ & Being the subject of excessive teasing and sarcasm & $3.1 \%$ & $2.5 \%$ & $24.7 \%$ & $21.8 \%$ \\
\hline $\mathrm{PI}$ & $\begin{array}{l}\text { Intimidating behaviours such as finger-pointing, } \\
\text { invasion of personal space, shoving, blocking your } \\
\text { way }\end{array}$ & $2.3 \%$ & $2.2 \%$ & $20.1 \%$ & $22.9 \%$ \\
\hline $\mathrm{PI}$ & Threats of violence or physical or actual abuse & $0.8 \%$ & $1.1 \%$ & $9.9 \%$ & $8.5 \%$ \\
\hline
\end{tabular}

Note: WR: Work-related bullying, PR: Personal-related bullying, PI: Physically intimidating bullying 
Table 15

Classification of respondents by exposure to bullying by NAQ- $R$, \% within sex

\begin{tabular}{lll}
\hline Exposure to bullying & Males & Females \\
\hline Bullied & $22.7 \%$ & $20.7 \%$ \\
Bullied occasionally & $25.2 \%$ & $26.0 \%$ \\
Not bullied & $52.2 \%$ & $53.3 \%$ \\
\hline
\end{tabular}

Being self-employed appears to provide protection from bullying for both males and females (see Table 16). Working in the private sector was associated with reduced bullying for males compared to government employment, but this was not seen for female participants. In the government sector, men were more likely than women to be bullied.

Table 16

Classification of respondents by exposure to bullying by NAQ-R, \% within sex by employer

\begin{tabular}{|c|c|c|c|c|c|c|}
\hline \multirow[b]{2}{*}{ Exposure to bullying } & Males & Females & Males & Females & Males & Females \\
\hline & \multicolumn{2}{|c|}{ Self-employed } & \multicolumn{2}{|c|}{ Government Sector } & \multicolumn{2}{|c|}{ Private Sector } \\
\hline Bullied & $10.7 \%$ & $6.7 \%$ & $26.9 \%$ & $18.1 \%$ & $20.9 \%$ & $23.4 \%$ \\
\hline Bullied occasionally & $21.4 \%$ & $23.3 \%$ & $28.9 \%$ & $28.8 \%$ & $22.8 \%$ & $23.7 \%$ \\
\hline Not bullied & $67.9 \%$ & $70.0 \%$ & $44.2 \%$ & $53.1 \%$ & $56.3 \%$ & $52.9 \%$ \\
\hline$\chi^{2} p=$ & .86 & & .024 & & .63 & \\
\hline
\end{tabular}

Table 17 indicates that across areas of work, the level of bullying varied $\left(\chi^{2}=43.5, d f=\right.$ $14, N=1,136 p<.001)$ with law enforcement and tourism/hospitality having the highest levels of bullying. This contrasted with ICT/telecommunications having the lowest levels of bullying. This variation in bullying across different sectors of the economy may be a concern when a mainstay of the economy, tourism/hospitality, has one of the highest levels of bullying.

\section{Table 17}

Exposure to bullying by $N A Q-R, \%$ within area of work

\begin{tabular}{lcccc}
\hline \multirow{2}{*}{ Area of work } & \multicolumn{3}{c}{ Exposure to bullying } \\
\cline { 2 - 5 } & Not bullied & Occasionally bullied & Bullied & $N$ \\
\hline Tourism/hospitality & 48.0 & 21.4 & 30.6 & 229 \\
Law enforcement & 33.3 & 36.2 & 30.5 & 141 \\
Finance & 56.2 & 21.2 & 22.7 & 203 \\
Law & 52.3 & 26.2 & 21.5 & 65 \\
Health & 56.8 & 23.2 & 20.0 & 125 \\
Sales & 57.5 & 23.9 & 18.5 & 113 \\
Education & 57.6 & 26.9 & 15.6 & 212 \\
ICT & 62.3 & 27.1 & 10.4 & 48 \\
\hline
\end{tabular}

This table is not disaggregated by sex as no sex differences between bullying classifications by area of work were found, $\chi^{2}$ $p>.05$. 


\section{Discussion}

This paper details the first known study to report on bullying in the Bahamian workplace. As such, it enables us to recognise that bullying occurs in the Bahamian workplace and to start to assess its extent. Some participants appeared to appreciate that there was a "normal" atmosphere of workplace bullying, "Nothing extreme from managers outside the normal Bahamian system", and this may be indicating that bullying is more prevalent here than elsewhere. Overall, the self-perception of bullying suggests a higher level of bullying than elsewhere, say in Great Britain, where across various sectors of the economy, between $83-95 \%$ reported not being bullied (data from a 2000 study reported in Illing et al., 2016). Illing et al. (2016) also cited a 2000 study from the United Kingdom in which $15 \%$ of participants reported being victims of bullying. Nielsen et al. (2010) reported results from various countries which indicated bullying occurrences of between $11-18 \%$. The NAQ-R provide data which are comparable to studies across countries. These figures suggest that, in general, the figures from this study are higher than those reported elsewhere. For example, in the study of Lewis et al. (2008), 88\% reported never or rarely "Being ordered to work below your level of competence" compared to our figure of just over $52 \%$ (Table 14).

Using data from the 2019 Labour Force Survey (Bahamas Department of Statistics, 2019 December), we can use the figures from this study to get an overall figure of bullying in the workplace. Weighting our figures by the numbers of males and females in the workforce, we can estimate that the prevalence of bullying is $21.7 \%$. This suggests that if the results from this study are indicative of bullying in the wider workforce, then The Bahamas suffers from a relatively high rate of bullying. Further, given that the tourism/hospitality industry appears to have one of the higher rates of bullying, this may help to explain the concerns which are expressed about customer service, etc. by visitors (Hartnell, 2015). If, as Table 8 suggests, $60-69 \%$ of those bullied want to leave their job, it is understandable that customer service suffers and, consequently, the economy.

While the study indicates that negative workplace behaviours are relatively common, overall women are no more at risk of being bulled than men. This is despite women having more education than men, which might be thought to be a protective factor from bullying. However, the data indicate that men's and women's experiences of bullying are not necessarily similar. The experiences of violence of men and women outside of the workplace appear to differ in the way they alter the risks of being bullied in the workplace. This is explicitly so particularly in the case of female victims; for example: "I have been sexually harassed. it made me very uncomfortable". Another participant reported, "My supervisor wanted to sleep with me and because I refused he would deny me days off and talk about me with my co-workers." Thus, workplace bullying can be added to the list of genderbased violent behaviours as well as the expression of homophobic attitudes. As one respondent said, "I'm Gay and it makes me feel unsafe and humiliating because they gossip about my sexuality and makes threats to me."

However, it should be noted that while this study did not investigate who the victimizers were, as it was focused on victims of workplace bullying, some of the participants' responses indicated that managerial styles may contribute to bullying. As one participant reported, "I have had a supervisor who shouted at me and then spoke about me 
as though I was not there, and then she purposely ignored me. But it just shows that not everyone who has qualifications has the people skills to be a manager." However, coworkers were also bullies: "I have had rumours spread about me by colleagues because of the praises I got from my CEO for being a great employee. Therefore, rumours were made that I was sleeping with the CEO, which is why I get so much praises." These comments were consistent with the results in Table 12 which showed that those in lower positions of authority were more likely to be bullied. This would suggest that mangers may be drivers of workplace bullying and may further suggest that those who are currently promoted to managerial roles may lack the skills and training to effectively manage those who report to them.

The data indicate that higher levels of bullying are experienced in the tourism and hospitality sector (Table 17). As tourism related activities are of prime importance to the country (Bahamas Investment Authority, 2011), the result requires further investigation. Tourism/hospitality is supported by a wide range of employment, and so future research could focus on the different constituents of the tourism sector. Around $21 \%$ of the workforce is employed in the government sector (Bahamas, Department of Statistics, 2019 December). This study indicated that, in this sector, males were more likely than females to be subjected to bullying, so this may be a finding that warrants further study due to the fact that one in five workers is employed by government agencies, etc.

The more common bullying activities in Table 14 indicate that work related bullying actions are most common, followed by personal related bullying and then physically intimidating bullying. This suggests that bullying in the Bahamian workplace revolves around power related aspects of workforce management. However, as one participant indicated such elements can become personal and gendered:

It feels like modern day slavery or at times sexism when issued top down or like gender bias when it's from an opposite gender. It feels like the person is insensitive of the cultural struggles or that of females. When this happens it leads to district [conflict?] and this does not allow the company to flourish. At times there's lack of understanding by single persons to married persons, same as non-parents to fathers/mothers. Black crab syndrome still pervades and the custom of "curry favour" due to background still exists and govern how one is treated. To rise above and push through is resistance and 2 or more who do this is considered a faction and moves against the grain. So often the generalised bullying becomes amplified and really turns into what I think are school yard games. True feelings are formed and the things expressed are personal and injurious... emotional abuse which I think is deeper and longer lasting builds and as victim a wall and distrust against the issuers build. Experiencing this first-hand, I note the team, work output, and organisation all suffer from lack of synchrony. (Participant C, 2020)

The participant's comments suggest that the work atmosphere does not encourage cooperation and collaboration between coworkers, so lateral and vertical bullying occur (Waschgler et al., 2013).

The results demonstrate that both males and females can feel bullied in the workplace. For some, workplace bullying is a continuation of negative experiences at home, in school and in adult social life. Also, those whose lives 
have involved moving from one negative space to another may be at greatest risk of exhibiting the psychological distress associated with workplace bullying (Nielsen et al., 2012). This, in turn, may suggest that workplace bullying is a manifestation of negative experiences early in life and so again emphasizes the importance of positive parenting practices, for example, Turns and Sibley (2018). Parenting practices which enhance violent tendencies of children when adults can contribute to workplace bullying (Notelaers et al., 2018).

Further, given the linkages between violence in the homes and schools and workplace bullying, the importance of addressing domestic violence should not be underestimated in order to not only protect the immediate victim, but also to disrupt the pipeline of children who may subsequently become victims of bullying at school (Baldry, 2003) and then in the workplace. The fact that no link was found between physical discipline in the home and workplace bullying for men, may arise from their suffering such a high rate of violence that violence is a norm in their lives to which they have become accustomed. However, as corporal punishment is linked with violence in later life (Ohene et al., 2006) this violence could also be manifested in the workplace. This may explain why almost one in ten participants had been the victim of threats of violence or physical abuse or actual abuse, Table 14. The mental effects of bullying were also mentioned by participants who reported "Mental, emotional bullying", "Mentally. I'm depressed", which is consistent with Theorell et al. (2015) as well the Caribbean as in Devonish's 2013 study from Barbados.

While workplace bullying is apparently no more common for females than males, the patterns of bullying are different between the sexes, for example, experiences of being humiliated. In some instances, this may have been linked to the examples of bullying of women which included sexual harassment. However, what may be of most importance is that, as this study suggests, the level of bullying in The Bahamas exceeds workplace bullying levels elsewhere. This alone is a concern.

Given the associations of workplace bullying with behaviours of concern within the participant's households and school experiences, it is apparent that the seeds of workplace bullying are essentially planted in the home. This is consistent with concerns expressed in the Bahamian media (Martin, 2019) and elsewhere (Fielding et al., 2016). This again suggests that negative parenting practices and the associated upbringing of children can have a negative impact when adults are at work and can be detrimental to the economy of the country. Altering these practices is a long-term, but necessary, project. In the short-term, this study suggests that human resource personnel may need to give greater emphasis to the training of managers so that the workplace atmosphere can become more welcoming and engaging. As one respondent said, "Sometimes I preferred to stay home because I felt like I was under intense scrutiny. In order to cope I conformed with my environment. I did what they wanted. I come to work on time prepared to work and then I go home when I am off."

\section{Limitations of the study}

In interpreting these results, we need to be aware that the dataset arose from a snowball sample obtained using social media groups. While this sample cannot be expected to result in a sample which represents the characteristics of the Bahamian workforce, it permitted a relatively large number of people to participate. This allows for linkages to be established between the experiences of participants. The complexity of our work 
lives, in that some people have multiple jobs, means that these people inhabit different workplaces and so may be subject to varying degrees of bullying in these different places. For this group, to speak of workplace bullying as arising from a singular workplace experience is clearly a simplification. Future research could, amongst other avenues, investigate selected segments of the economy to examine the nature of workplace bullying in greater detail which may be specific to that particular segment.

\section{Acknowledgements}

The author is grateful Ms. Margo Blackwell for encouraging him to undertake this research, to Ms. Virginia Ballance for assistance with the literature and to students in the research methods class SSOC200 of Spring 2020 for their assistance in the data collection and input into the questionnaire. 


\section{References}

Anjum, A., Muazzam, A., Manzoor, F., Visvizi, A., Pollock, G., \& Nawaz, R. (2019). Measuring the scale and scope of workplace bullying: An alternative workplace bullying scale. Sustainability, 11(17), 4634.

https://doi.org/10.3390/su11174634

Bahamas Department of Statistics. (2019).

Table 1: University of the Bahamas graduates by degree, division and sex, school year, 2018-2019. Labour Market Information Newsletter, 32(43), 1. https://www.bahamas.gov.bs/wps/wcm/co nnect/55f2328c-b71c-41f4-9bfaa699fb3000a9/NEWSLETTER+20182019+WORD+SHEET.pdf?MOD=AJPE RES

Bahamas Department of Statistics. (2019, December). Preliminary results: Labour force survey, New Providence [Press release].

https://www.bahamas.gov.bs/wps/wcm/co nnect/6cbfd694-837f-49e5-9e6994cc51bb8799/FOR+PRESS+RELEASE_ Labour+Force+Survey+December+2019. pdf?MOD=AJPERES

Bahamas Investment Authority. (2011).

Economic environment.

https://tinyurl.com/BahamasInvestmentAu thority 2011

Bahamas National Task Force for Genderbased Violence. (2015). Strategic plan to address gender-based violence. Ministry of Social Services and Community Development. https://www.bahamas.gov.bs/wps/wcm/co nnect/3be7c3ad-862c-4c0f-ac44a2833552e00b/GBV+REPORT.Final.+Au gust2015.pdf?MOD=AJPERES
Baldry, A. C. (2003). Bullying in schools and exposure to domestic violence. Child Abuse \& Neglect, 27(7), 713-732. https://doi.org/10.1016/S01452134(03)00114-5

Bethel, N., \& Fielding, W. J. (2020). Consent prior to sexual intercourse. [Manuscript submitted for publication]. Social Sciences, University of The Bahamas.

Bittersweet end to summer. (2011, August 17). Nassau Guardian. https://thenassauguardian.com/2011/08/17 /bittersweet-end-to-summer/

Campanini, P., Punzi, S., Carissimi, E., \& Gilioli, R. (2006). Le differenze di genere nelle situazioni di mobbing [Gender differences in workplace bullying]. $\mathrm{La}$ Medicina del Lavoro, 97(5), 699-706. http://hdl.handle.net/2434/51233

Clark, C. M., Landrum, R. E., \& Nguyen, D. T. (2013). Development and description of the Organizational Civility Scale (OCS). Journal of Theory Construction \& Testing, 17(1), 11-17. https://tinyurl.com/y2e92o7e

Cowie, H., Naylor, P., Rivers, I., Smith, P. K., \& Pereira, B. (2002). Measuring workplace bullying. Aggression and Violent Behavior, 7(1), 33-51. https://doi.org/10.1016/S13591789(00)00034-3

The crime of bullying. (2014, August 7). Caribbean DevTrends. https://blogs.iadb.org/caribbean-devtrends/en/crime-bullying/ 
de Smet, P., Sans, S., Dramaix, M., Boulenguez, C., de Backer, G., Ferrario, M., Cesana, G., Houtman, I., Isacsson, S. O., Kittel, F., Ostergren, P. O., Peres, I., Pelfrene, E., Romon, M., Rosengren, A., Wilhelmsen, L., \& Kornitzer, M. (2005). Gender and regional differences in perceived job stress across Europe.

European Journal of Public Health, 15(5), 536-545.

https://doi.org/10.1093/eurpub/cki028

Devonish, D. (2013). Job demands, health, and absenteeism: Does bullying make things worse? Employee Relations, 36(2), 165-181. https://doi.org/10.1108/ER-012013-0011

Einarsen, S., Hoel, H., \& Notelaers, G. (2009). Measuring exposure to bullying and harassment at work: Validity, factor structure and psychometric properties of the Negative Acts Questionnaire-Revised. Work \& Stress, 23(1), 24-44. https://doi.org/10.1080/026783709028156 73

Fazio, M. V., \& Pinder, E. (2014). In pursuit of employable skills: Understanding employers' demands: Analysis of the Bahamas' 2012 wages \& productivity survey. Inter-American Development Bank. https://publications.iadb.org/publications/ english/document/In-Pursuit-ofEmployable-Skills-UnderstandingEmployers-Demands-Analysis-of-theBahamas-2012-Wages-and-ProductivitySurvey.pdf

Ferguson, I. (2012, July 2). Workplace bullying undermines firms. The Tribune. http://www.tribune242.com/news/2012/jul /02/workplace-bullying-underminesfirms/
Fielding, W. J. (2014). The impact of college graduates on Bahamian society: With emphasis on graduates from The College of The Bahamas. International Journal of Bahamian Studies, 20(2), 1-11. https://doi.org/10.15362/ijbs.v20i2.209

Fielding, W. J. (2019). Perceptions of crime and safety in The Bahamas.

ResearchGate. https://doi.org/10.13140/RG.2.2.17410.43 204

Fielding, W. J., \& Ballance, V. C. (2019). Learning gender-based attitudes in The Bahamas. International Journal of Bahamian Studies, 25, 1-15. https://doi.org/10.15362/ijbs.v25i0.339

Fielding, W. J., Ballance, V. C. F., Strachan, I. G. (2016). Violence in The Bahamas. University of The Bahamas/Media Enterprises. https://www.dloc.com/AA00078778/0000 2

Fielding, W. J., Ballance, V. C., Smith, P., Veyrat-Pontet, A., \& Sutton, H. (2019). Our prisoners. A collection of papers arising from a 2016 survey of inmates at the Bahamas Department of Correctional Services facility at Fox Hill. InterAmerican Development Bank. https://publications.iadb.org/publications/ english/document/Our_Prisoners_A_Colle ction_of_Papers_Arising_from_a_2016_S urvey_of_Inmates_at_The_Bahamas_Dep artment_of_Correctional_Services_Facilit y_at_Fox_Hill_en_en.pdf

Hanna, C. (2020, January 13). When will the bullying stop? [Letter to the Editor]. The Tribune. http://www.tribune242.com/news/2020/ja n/13/letters-when-will-bullying-stop/ 
Hanna, C. A. (2017). Solutions to the murder problem. National Anti-Drug Secretariat, Ministry of National Security. http://ufdc.ufl.edu/AA00061956/00001

Hartnell, N. (2015, December 15). Bahamas 'must get it right first time' on tourism value. The Tribune.

http://www.tribune242.com/news/2015/de c/16/bahamas-must-get-it-right-first-timetourism-value/

Illing, J., Thompson, N., Crampton, P., Rothwell, C., Kehoe, A., \& Carter, M. (2016). Workplace bullying: Measurements and metrics to use in the NHS: Final report for NHS employers. Newcastle University School of Medical Education.

https://www.nhsemployers.org/ /media/E mployers/Documents/Campaigns/NHS_E mployers_Bullying_Measures_Final_Rep ort.pdf

Lenhard, W. \& Lenhard, A. (2016).

Computation of effect sizes.

Psychometrica.

https://www.psychometrica.de/effect_size. html

Lewis, D., Sheehan, M., \& Davies, C. (2008). Uncovering workplace bullying. Journal of Workplace Rights, 13(3), 281-301. https://doi.org/10.2190/WR.13.3e

Martin, M., (2019, October 27). When adults bully adults, kids suffer [Letter to the Editor]. http://www.thebahamasweekly.com/publi sh/letter-to-the-

editor/Melissa_Martin_When_adults_bull y_adults_kids_suffer63687.shtml

Nielsen, M. B., Hetland, J., Matthiesen, S. B., \& Einarsen, S. (2012). Longitudinal relationships between workplace bullying and psychological distress. Scandinavian Journal of Work, Environment \& Health, 38(1), 38-46.

https://www.jstor.org/stable/41508862

Nielsen, M. B., Matthiesen, S. B., \& Einarsen, S. (2010). The impact of methodological moderators on prevalence rates of workplace bullying: A meta-analysis. Journal of Occupational and Organizational Psychology, 83(4), 955979.

https://doi.org/10.1348/096317909X4812 56

Notelaers, G., \& Einarsen, S. (2013). The world turns at 33 and 45: Defining simple cutoff scores for the Negative Acts Questionnaire-Revised in a representative sample. European Journal of Work and Organizational Psychology, 22(6), 670682.

https://doi.org/10.1080/1359432X.2012.6 90558

Notelaers, G., Van der Heijden, B., Guenter, H., Nielsen, M. B., \& Einarsen, S. V. (2018). Do interpersonal conflict, aggression and bullying at the workplace overlap? A latent class modeling approach. Frontiers in Psychology, 9, 1743.

https://doi.org/10.3389/fpsyg.2018.01743

Ohene, S. A., Ireland, M., McNeely, C., \& Borowsky, I. W. (2006). Parental expectations, physical punishment, and violence among adolescents who score positive on a psychosocial screening test in primary care. Pediatrics, 117(2), 441447. https://doi.org/10.1542/peds.20050421 
Onuoha P., Drayton-Bailey, A., Dais, R., James-Fough, C., Sherma Hinneh, D., Alphonso-Lootawan, A., \& Ezenwaka, C. (2014). Registered nurses' workplace bullying experiences at a Caribbean teaching hospital. Asian Academic Research Journal of Multidisciplinary, 20(1), 206-222.

https://www.researchgate.net/publication/ 266308019_Registered_Nurses'_Workpla ce_Bullying_Experiences_at_a_Caribbean _Teaching_Hospital

Ranger, N. (2018, May 14). Police advice: From playgrounds to the workplace tackling the bullies. The Tribune. http://www.tribune242.com/news/2018/m ay/14/police-advice-playgroundsworkplace-tackling-bulli/

Sansone, R. A., \& Sansone, L. A. (2015). Workplace bullying: A tale of adverse consequences. Innovations in Clinical Neuroscience, 12(1-2), 32-37. https://www.ncbi.nlm.nih.gov/pmc/article s/PMC4382139/pdf/icns_12_1-2_32.pdf

Singh, R. (2018). The moderating role of workplace bullying in the embeddednessturnover intention relationship. Journal of Organisation \& Human Behaviour, 7(4): 14-21.

https://www.researchgate.net/profile/Rian n_Singh/publication/336035567_The_Mo derating_Role_of_Workplace_Bullying_i n_the_embeddedness__turnover_intention_relationship/links/5d e6aa5792851c83645fbfe9/The-

Moderating-Role-of-Workplace-Bullyingin-the-embeddedness-turnover-intentionrelationship.pdf

Strachan, R. (2012, October 4). Political bullying. [Letter to the Editor]. The Nassau Guardian. https://thenassauguardian.com/2012/10/04 /political-bullying/

Sutton, H., \& Álvarez, L. (2016). How safe are Caribbean homes for women and children? Attitudes toward intimate partner violence and corporal punishment. Inter-American Development Bank. https://doi.org/10.18235/0000546

Theorell, T., Hammarström, A., Aronsson, G., Bendz, L. T., Grape, T., Hogstedt, C., Marteinsdottir, I., Skoog, I., \& Hall, C. (2015). A systematic review including meta-analysis of work environment and depressive symptoms. BMC Public Health, 15(1), 738. https://doi.org/10.186/s12889-015-1954-4

Tonini, S., Lanfranco, A., Dellabianca, A., Lumelli, D., Giorgi, I., Mazzacane, F., Fusi, C., Scafa, F., \& Candura, S. M. (2011). Work-related stress and bullying: Gender differences and forensic medicine issues in the diagnostic procedure. Journal of Occupational Medicine and Toxicology (London, England), 6(1), 29. https://doi.org/10.1186/1745-6673-6-29

Trépanier, S. G., Fernet, C., \& Austin, S. (2013). Workplace bullying and psychological health at work: The mediating role of satisfaction of needs for autonomy, competence and relatedness. Work \& Stress, 27(2), 123-140. https://doi.org/10.1080/02678373.2013.78 2158

Tuckey, M. R., \& Neall, A. M. (2014). Workplace bullying erodes job and personal resources: Between-and withinperson perspectives. Journal of Occupational Health Psychology, 19(4), 413-424. https://doi.org/10.1037/a0037728 
Turns, B. A., \& Sibley, D. S. (2018). Does maternal spanking lead to bullying behaviors at school? A longitudinal study. Journal of Child and Family Studies, 27(9), 2824-2832. https://doi.org/10.1007/s10826-018-1129$\mathrm{x}$

Van Dyck, S. E. (2013). Horizontal workplace aggression and coworker social support related to work-family conflict and turnover intentions. [Master's thesis, Portland State University]. https://doi.org/10.15760/etd.652

Vartia, M. A. (2001). Consequences of workplace bullying with respect to the well-being of its targets and the observers of bullying. Scandinavian Journal of Work, Environment \& Health, 27(1), 6369. https://doi.org/10.5271/sjweh.588
Vega, G., \& Comer, D. R. (2005). Sticks and stones may break your bones, but words can break your spirit: Bullying in the workplace. Journal of Business Ethics, 58(1-3), 101-109. https://doi.org/10.1007/s10551-005-14227

Waschgler, K., Ruiz-Hernández, J. A., LlorEsteban, B., \& Jiménez-Barbero, J. A. (2013). Vertical and lateral workplace bullying in nursing: Development of the hospital aggressive behaviour scale. Journal of Interpersonal Violence, 28(12), 2389-2412. https://doi.org/10.1177/088626051347902 7

Zabrodska, K., \& Kveton, P. (2013). Prevalence and forms of workplace bullying among university employees. Employee Responsibilities and Rights Journal, 25(2), 89-108. https://doi.org/10.1007/s10672-012-9210-x 